DOI 10.14746/ssp.2020.2.8

Lucyna RAJCA

Jan Kochanowski University in Kielce

ORCID: 0000-0002-3947-1729

\title{
Management reforms in the Polish and Hungarian local government
}

\begin{abstract}
The study aims to compare management reforms in the Hungarian and Polish local government structures which were introduced at the beginning of the transformation of the socio-political system and during the first two decades of the 21 st century. The analyses show that local governments in both countries have implemented solutions derived from different management paradigms, which are in many respects contradictory. In the process of implementing management reforms in the local governments of the two countries there have been both convergent and divergent trends. The public administration reforms in Hungary after 2010 reflect a coherent vision of a strong and centralized state and are intended to ensure effective resolution of social problems. The market and civil society have been given a subordinate role. As far as the Polish local government model is concerned, currently it is difficult to indicate one organizational model constituting a coherent whole.
\end{abstract}

Key words: management models, Poland, Hungary

\section{Introduction}

7 his study aims to compare management reforms in the Hungarian and Polish local government systems and to indicate convergence and divergence in this respect in both countries. In addition, it attempts to indicate the public administration model that has emerged in Poland and Hungary as a result of public management reforms. ${ }^{1}$

The first part presents an outline of the main public management paradigms to provide a better understanding of the trajectories of Hungarian and Polish reforms. Then, changes related to the privatization of municipal services in the Hungarian and Polish local government models and

1 The article is an English version of a modified chapter of the author's book entitled: Reformy samorzadu terytorialnego na Wegrzech $i$ w Polsce, Dom Wydawniczy Elipsa, Warszawa 2019, pp. 91-112. 
remunicipalization are discussed. The following part presents the changes inspired by participatory governance. The final part indicates convergence and divergence in the respect of management reforms and tries to determine the public administration model.

The work uses a comparative approach to show convergence and divergence within management reforms in the Hungarian and Polish local government systems and an institutional and legal approach for analyzing legal acts and documents. To explore the topic, scholarly literature was mainly used, but legal acts, documents, and materials obtained from websites were also examined. Polish scholarly literature lacks a comparative study on management reforms in the Polish and Hungarian local government.

\section{The main paradigms of management reforms}

Over the past century, four major public governance models have evolved: Weberian, New Public Management (NPM), Public Governance, and neo-Weberian. In the Weberian model, organizations are hierarchical, public officials are recruited on the basis of qualifications, and there is a clear separation between the public and private spheres. The role of the administration is to implement laws in a professional, reliable and lawful way. Traditionally, public management was based on a dichotomy between politics and administration. The provision of services was a major task of the local government as part of the welfare state. Experts - officials and politicians to be precise - specified the needs of the local community. This way of understanding public administration began to change in the post-war period with the expansion of the welfare state and the increasing number and complexity of its functions.

In the 1980s, reforms inspired by the new public management (NPM) concept were introduced. In Central and Eastern Europe the popularity of this paradigm reached a peak in the initial stage of political transformation and was welcomed with great enthusiasm. The private sector and its market-oriented organizational and operational principles were the common basis for reforms inspired by new public management. Their use in the public sector was to be a remedy for public administration failures. In the period when the new public management paradigm dominated, it was believed that the private sector was more effective than the public one, and public services greatly benefited from market competition mecha- 
nisms. This resulted in the privatization of some public services, their outsourcing, and the creation of public-private partnerships. The concept promoted reducing the public sector and limiting the role of the state.

As a result of the implementation of this paradigm, networks of actors providing public services and functioning mainly outside the direct control of public authority started to emerge. Observers pointed to the unintended and often negative effects of NPM reforms, such as increasing the fragmentation of public administration, problems with coordination, the erosion of social cohesion, weakening the ethics of public services (Van de Wale et al., 2016, p. 2), unequal access to public services, replacing state monopolies with private ones, and the failure to improve the quality of services and reduce their costs. As a result of the processes of radical privatization, deregulation and decentralization, the state (government) was deprived of instruments to solve many problems and lost public confidence. Experience has proved that the market cannot function without a strong and efficient state performing the role of a regulator, coordinator, strategist and corrector of market failures (Sześciło, 2014, p. 17). Developing reforms based on new public management was opposed, both locally and regionally. By 2005 the concept had been abandoned ${ }^{2}$ and the importance of public administration began to be emphasized (Kopyciński, 2016 , p. 27). The international economic crisis of 2008 resulted in even stronger criticism of neoliberal dogmas. For this reason, decentralization and privatization, previously supported by NPM, slowed down in Europe.

At the end of the 1990s, there was a shift towards another set of ideas regarding the management of local public services, referred to as local governance, which provides local government with a new role, namely that of a coordinator that aims to combine and control complex processes. Governance requires partnerships and the extension of the scope and mechanisms of participation, as well as the involvement of civil society in the creation and implementation of public policy. Partner cooperation makes it possible to use the knowledge, skills, and resources of many different participants to solve problems. Local authorities faced the challenge of creating conditions for cooperation and developing methods for coordinating the interests of various social groups.

Local government reforms carried out in many countries in accordance with the concept of governance revealed the dissonance between the

${ }^{2}$ Criticism of new public management does not mean a complete failure of this management method. 
theory and social reality. Research has shown no convincing evidence of the positive effects of governance implementation in either service delivery or democratic renewal (Rajca, 2012, pp. 156-157). Therefore, the question of the effectiveness of using participatory mechanisms for real change remains open. When implementing governance, the institutional context and experience in cooperation with the local community are important, as the functioning of administration depends more on soft law norms, shaped by the nature of social relations, citizens' activity and the ethics of governance (Kachniarz, 2018, p. 161). In post-socialist countries, both NPM and governance were readily accepted, at least on a declarative level, but the weakness of the market and civil society, as well as public institutions, did not allow for the full implementation of these concepts (Pawłowska, 2018, p. 49). According to Tiina Randma-Liiv, the reason for the partial failure in implementing the NPM and governance in post-socialist countries was the lack of a well-functioning public administration based on Weberian principles (Randma-Liiv, 2008/2009, p. 79).

After a period of reducing the role of the state for the benefit of the free market and social actors, the concept of neo-Weberianism (the neoWeberian state) emerged. It postulated the reinforcement of the instrumental and controlling capabilities of the state. The neo-Weberian model of public management combines elements of the Weberian model (the centralization of power - the state as the main coordinator of activities aimed at solving problems, hierarchy, impartiality, legality, political neutrality, professionalism) and several elements taken from NPM and governance (greater efficiency and effectiveness, high-quality public services, performance-orientation, professional management, strengthening sensitivity to the needs of citizens, public consultations and the direct involvement of citizens). The methods used in the private sector may play a subsidiary role, but the state remains the most important actor with its principles, methods, and culture. Neo-Weberianism means the increased activity of public administration at every level, especially central administration (Kudłacz, 2015, pp. 163-165).

Although the nationalization of public service management could already be observed at the beginning of this century (health care reform in the Nordic countries), its importance has increased since the international financial crisis from the end of the first decade of the 21 st century. This crisis highlighted the negative consequences of a highly deregulated political and economic system. There were more and more calls for state regulation by the state, and even the renationalization or remunicipali- 
zation of privatized tasks and activities (Kuhlmann, Wollmann, 2014, p. 173). Probably the strongest nationalization took place in Hungary.

\section{Privatization and remunicipalization in Hungary and Poland}

Both in Poland and Hungary in the socialist period the state had a monopoly on the provision of public utilities. As a result of the political transformation in both countries, these services (water, sewage, public transport, etc.) were transferred to local governments in 1990. At the same time, relevant institutions passed into their ownership. In Hungary, municipalities used municipal budget institutions to provide public services, especially water, sewage, and heating. They also outsourced their own businesses to carry out some tasks. In Poland, enterprises providing services such as water, sewage management, and heating were, like in Hungary, usually transformed into municipal budget institutions or municipal capital companies. Budget units without legal personality provided services such as kindergartens, schools, and residential care homes. Services such as street cleaning, the maintenance of green spaces and funeral services were, however, much more often privatized.

Under the influence of the NPM concept and growing financial pressure, Hungarian municipalities began selling public utilities and enterprises to private investors. These included municipal water plants and electrical service provider companies (Kuhlmann, Wollmann, 2014, p. 188). Many municipalities started to set up public-private partnerships (PPPs). Most enterprises owned by the counties (megyék) were also sold to private investors. In Hungary, there was a tendency to sell public enterprises to West European monopolistic companies. According to Tamás M. Horváth, the reason for the privatization of public enterprises was, firstly, the belief that private companies were more effective than public ones. Secondly, their value (price) increased as a result of using tender procedures, which was important in the context of the budgetary constraints of municipalities. Thirdly, large western European companies were ready to enter the newly opened market in Eastern Europe (Horváth, 2016, p. 189). Pressure on marketization and competition from the liberalization policy of the European Union was also significant.

Hungarian municipalities also outsourced public services much more frequently than municipalities in other Central and Eastern European countries (OECD, 2008, p. 29). For example, local government water 
supply companies commissioned the supply of water to private and especially foreign companies. The transfer of tasks to external entities at the local level was also present in health care, cultural services (e.g. libraries) and social services. This resulted in the extension of the range of services provided by the rapidly growing NGO sector as well as churches and private charities. Contracts with external service providers were often concluded after competitive tenders. Contracting services and functional privatization were widespread strategies in Hungary (Kuhlmann, Wollmann, 2014, pp. 198-199).

Actions taken in Hungary after 1990 to develop the economy did not bring satisfactory results. The local public administration was not able to provide good quality services in a professional manner. Also, Hungary was severely affected by the economic crisis and the state was forced to redefine its development structure. In 2005-2006 spending on social services was reduced. Pursuant to state directives, public service contracts were awarded to budgetary institutions at the expense of NGOs and commercial entities. Since 2010, the trend towards greater public control over services has been more and more visible. Larger municipalities and subsequently the central government began to buy back shares in privatized enterprises providing public services. Public utilities have been nationalized (taken over from local governments and foreign investors). At the same time, "insourcing" has replaced the previously widespread outsourcing. Such changes in the provision of public services have also occurred in other European countries, but in Hungary the legal conditions and actions have changed more radically (Horváth, 2016, pp. 190-191).

The main feature of the trend after 2010 was the government's opposition to privatization, which was perceived as leading to excessive prices for services. Research conducted in 2012-2013 showed that both the government and Hungarian councilors were strongly against privatization, while Polish councilors mostly approved of it, which indicates a quite different approach to NPM reforms at that time in both countries (Heinelt, Krapp, 2016, p. 36). The Hungarian central government has also been skeptical about public-private partnerships (PPPs) as a form of public investment implementation. It has strongly interfered with market processes. The providers of utilities (electricity, gas, waste management, heating) have been obliged to reduce prices for users and a centrally levied tax has been imposed on them. The newly built infrastructure automatically becomes the property of the state or municipalities, although private enterprises can still provide services. To gain more direct power 
over the activities of public services, municipal holding companies have been increasingly present in Hungarian cities (Horváth, 2016, p. 194). Hungarian researchers have predicted that the nationalization of the services provided before the reform by local governments or the private sector will continue not only in municipal infrastructure but also in social policy (Pálné Kovács, 2015, p. 18). As a consequence of the reform of the Hungarian public administration after 2010, the role of non-state actors has been reduced. The share of the production of public goods and services commissioned to external entities has decreased. The changes in Hungary are defined as developing a new model of local democracy, which is no longer based on the neoliberal concept of the state or the principles of the NPM, but on the model of the neo-Weberian state in which government bodies play a dominant role in public affairs. Most of the results of the decentralization introduced during the transformation period have been eliminated (Horváth, 2016, p. 193). The local government system has become extremely centralized.

In Poland, at the beginning of the new millennium, a new system of service delivery was developed. Since Poland was under the influence of neoliberal economic doctrines, local government market solutions were preferred. Many municipal heating companies went private. In 2014, out of 349 licensed heating enterprises - 128 were owned by the private sector and 219 were public sector-owned, including 204 owned by municipalities. The heating industry is the most commercialized and at the same time the most privatized field of municipal economy. Prices for energy and heating are controlled by the state authorities - heating companies are required to submit tariffs for approval to the President of the Energy Regulatory Office. In 2010, at least 10 per cent was owned by foreign companies.

Unlike heating enterprises, the privatization of water supply companies is not popular in Poland. According to the Central Statistical Office data, in 2015 out of the total number of entrepreneurs involved in the collection, treatment, and supply of water (1,843 entities), commercial law companies and local government budgetary institutions constituted the largest share (38.14 per cent) and (30.28 per cent) respectively (GUS, 2015). In the vast majority of cases, municipalities were either the sole or majority owner of the water supply companies. Companies with foreign capital accounted for less than 1 per cent of all water utilities. In some cities, the management of water supply systems was entrusted to a privately-owned company. For example, in 1992, a joint-stock company was set up in Gdańsk. The company shareholders were the city of 
Gdańsk (49 per cent) and a French company (51 per cent). The contract expires after 30 years from the date of signing. In Katowice, the water supply is provided by Górnośląskie Przedsiębiorstwo Wodociągów S.A. (The Upper Silesian Water Supply System). About 80 percent of the company's shareholders are Śląskie Voivodship, and almost 20 percent are other shareholders (natural and legal persons). Other large cities have 100 per cent shares in water supply companies. In some medium-sized cities there has been partial privatization of water supply companies. However, it should be noted that the privatization of water supply companies in Poland is marginal as compared to the entire water supply market in the country (Odpowiedź Ministra Środowiska, 2016).

After 1990, public transport services were usually performed by municipal budget institutions or limited companies. In 2010, Parliament passed a law (ustawa $\mathrm{z}$ dnia 16 grudnia 2010), which stipulates that the roles of the organizer (municipalities and their associations) and the operator are separate from each other. The operator is a local government budgetary institution or an entrepreneur authorized to conduct business in the field of passenger transport, who signs a contract with the organizer of public collective transport for the provision of services. The market opened to free competition, but many municipalities gave their companies the status of internal operator for a transitional period (usually 15 years). In many large cities, only municipal companies are operators (Wąsowicz, 2018, pp. 138-144). Municipal companies can, therefore, remain monopolists in these services for a period of time. Foreign investors have not become important players in the market of local transport services (Mikuła, Walaszek, 2016, pp. 175-176).

As far as healthcare services are concerned, there has been an intensive development of many private medical practices, pharmacies, and clinics. Although there were plans to commercialize and privatize public hospitals, their implementation was progressing at a moderate pace. In 2016, the privatization of health care facilities became restricted. Selling shares or stocks in state-owned capital companies or local government units was banned if, as a result of the sale, these entities would lose their majority block of shares (ustawa $\mathrm{z}$ dnia 10 czerwca 2016). Personal social services, such as running residential care homes for the elderly and disabled, are usually run by local governments, but, to a significant extent, also by the Catholic Church or other religious organizations, as well as NGOs and private individuals (Mikuła, Walaszek, 2016, pp. 181). NGOs are playing an increasingly important role in the provision of social services. 
In the last few years, more and more Polish local government units, especially in large cities, have been carrying out tasks using public-private partnerships (PPP). Growing local government debt, government pressure to reduce it, as well as the possibility of using EU funds have additionally motivated local authorities to seek alternative forms of financing public investments. Between 2009 and 2016, 113 public-private partnership contracts were carried out. Most of these contracts involved the management of tourist and sports facilities, transport infrastructure and water and sewage management. The most expensive PPP project was the construction of a modern incineration plant in Poznan as part of the waste management system for the city of Poznan (PLN 925 million). Even though local governments have been increasingly interested in PPP, the experience thus far has not been satisfactory. This is due to many existing barriers to undertaking initiatives using PPP, including low awareness and insufficient knowledge of PPPs in the public sector and the high costs of economic and legal analysis.

Polish local government units, especially municipalities, use privatization and contracting services to varying degrees. Public support for liberalization and privatization seems to be weaker than at the beginning of this century. The attitude of Poles towards privatization is most often negative (Ministerstwo Skarbu Państwa, 2016, p. 20). Polish local governments are reluctant to sell municipal companies (for fear of being accused of corruption or sale of municipal assets, as well as to be able to offer employment in municipal companies to people with the "right" political connections) (Forum samorządowe, 2013). It should also be emphasized that in Poland there are nearly 60,000 local government organizational units that help local government authorities carry out the tasks assigned to them. The requirement to have many local government institutions undermines the sense of outsourcing many tasks or purchasing services from private suppliers and indirectly hinders the involvement of residents in improving the quality of life. In Poland, in terms of implementing the concept of new public management, any generalization would be too simplistic, as there is a wide variation in this respect among Polish local governments. Some municipalities still focus on the traditional way of providing services.

To sum up, it can be stated that the Hungarian public service delivery model can be defined as a transition from a centralized state model to a decentralized local government system, which was then subject to NPM-inspired reforms as well as increasing organizational and functional 
privatization (Kuhlmann, Wollmann, 2014, p. 198). It was again centralized as a result of delegating tasks to the state administration and limiting the role of municipalities as a service provider. This latest phase of changes has been compliant with the overall political transformation towards creating a non-liberal state in a country where decentralization has never been deeply rooted in public service management and governance (Péteri). In Poland, the evolution of local public service delivery methods was until recently similar to that in Hungary and probably typical of the eastern and central parts of the continent. However, the privatization process in the Polish local government was not radically interrupted as it was in Hungary. Also, centralization never reached the scale comparable to that of Hungary. The current government of Law and Justice is opposed to the privatization of companies and state property and has taken steps to rebuild them. The ruling party, led by Jarosław Kaczyński, seems to agree with the diagnosis made by the Hungarian Prime Minister regarding the adverse effects of the earlier privatization process and the divestment of national property.

In recent years, the neoliberal idea that "private is better than public" has lost much of its strength and credibility. There has been a trend in Europe towards the remunicipalization and nationalization of public assets and services. To overcome the global economic and financial crisis, national governments once more rely on state regulation in the public sector. Increasingly, citizens recognize the value of services being provided by the public sector. In Germany, for example, not only the privatization of municipal enterprises and facilities (assets) but also functional privatization has been rejected in an increasing number of petitions and local referenda. An example of the remunicipalization trends is the German energy sector (Kuhlmann, Wollmann, 2014, pp. 200-201). Hellmut Wollmann stated that the trend towards remunicipalization is caused by factors such as disappointment with the neoliberal belief that the private sector is superior to the public; the growing motivation of local authorities to regain control over municipal services and to obtain financial benefits from the provision of communal services; a change in political and cultural values; growing grassroots pressure in visible local referenda; and the expiry of concession contracts (Wollmann, 2016, pp. 323-324).

Hungary has been a unique case in this process since 2010 . As mentioned before, local authorities and their companies are buying back previously sold municipal assets or have started re-insourcing instead of prior outsourcing. It might seem that local government is making a "comeback" 
as an appropriate actor in the area of providing local services. However, as noted by Tamás M. Horváth, the events in Hungary are an example of de-municipalization rather than remunicipalization. This is because in Hungary, "there has been a move towards massive state intervention at the expense of public civic solutions" (Horváth, 2016, p. 198).

In Poland, it is hard to prove the existence of the phenomenon of remunicipalization which involves the purchase of previously sold municipal property. The documents of the Ministry of Treasury do not reveal such a process (Ministerstwo Skarbu Państwa, 2015; Ministerstwo Skarbu Państwa, 2016). Although the literature indicates individual cases of actions aimed at regaining control over previously privatized municipal enterprises, it does not seem to be a general tendency. Some cities have resigned from the services of external companies to manage municipal housing resources or collect parking fees (Swianiewicz, 2016, pp. 15-31; Swianiewicz, 2017, p. 26). Research conducted by Paweł Swianiewicz in 2014-2016 shows that the support of Polish mayors for the public provision of services and remunicipalization was among the lowest as compared with the 30 other analyzed European countries, while it was the highest for their Hungarian counterparts. Polish local leaders continued to be closer to the neoliberal service provision model. In Europe, there is a wide variation between countries in terms of their preferences regarding the privatization of local public services (Swianiewicz, 2017, pp. 21, 25).

\section{Participatory governance in Hungary and Poland}

In Hungary, the constitutional and statutory framework provided unique opportunities for creating an entirely new bottom-up power model. The law has provided for a universal initiative for residents of the municipality in relation to matters falling within the competence of the representative body, and the right to request a local referendum, while the representative body is obliged to organize an annual public assembly. The principle of openness of the operation of local government bodies has been made a rule. The creation of a legal framework in itself has not proved sufficient for democratic local policies. Neither the transparency of decision-making processes nor the participation of residents has increased. Internal political conflicts have decreased the number of stakeholders involved in the decision-making process, local government politicians have not treated civil society as partners, but only as voters. 
Also, as Ilona Pálné Kovács argues, networks around the local government system have been perceived as influential clients of party politicians performing various functions rather than conscious partnerships and development coalitions. Although there has been a development of civic organizations, their activity and their position in the sphere of local policies has been rather marginal (Pálné Kovács, 2012, pp. 184,188). New bodies such as development councils, youth councils, tourism committees, etc. have been usually imposed and represented the government's position. Local policies have not provided space for new forms of democracy and participation. So, as Ilona Pálné Kovác rightly pointed out, making the local governance "more open, receptive and 'democratic' is not a question of reforms of regulations and political programmes. In this field, 'path dependence' has a greater role, and democratic political culture cannot be prescribed like a recipe" (Pálné Kovács, 2012, pp. 193-194). Implementing institutional solutions in a social environment that is not prepared to use them usually does not produce the expected results.

The partnership principle has not brought a real breakthrough in the Hungarian public administrative culture due to the relatively weak civic sector, fragile local administrative resources, and the lack of trust or willingness to cooperate with local politicians and officials (Pálné Kovács, Region-Building, p. 80). Partnerships have not been as effective as expected, even in those cases where the participation of economic and social partners was a basic condition for applying for EU funds (Pálné Kovács, 2016, p. 802). Centralization processes have weakened participatory mechanisms in the functioning of the state. After 2010, the funding of civic sector organizations has been significantly reduced and made dependent on political loyalty. The institution of the referendum, local and national, has been weakened, for such reasons as increasing the referendum validity threshold and abolishing the consultative referendum.

In Poland, many legal possibilities of the participatory local government model have been introduced. At present, residents can participate in local referenda, consultations, collegial meetings of elected local government authorities, in the debate on the report on the state of the local government unit, in the procedure of the civic budget and the rural municipality (solectwo) fund, subsidiary units, youth city councils, senior councils, local initiatives, and legislative initiatives. There are no obstacles to the use of other forms of participation not specified in the law, such as citizens' courts, citizens' panels, and creating a vision of city development. 
The institutions existing in the Polish local government system allow a partner management model to be built.

Currently, however, institutionalized instruments of partnership and participation are used rather occasionally and are largely inspired by supranational (EU) institutions and national authorities, and are controlled by local authorities. Citizens are still treated more as local government clients than their partners (co-decision makers). Local authorities are generally moderately interested in involving residents in the management of public affairs. The success of decentralization has not resulted in widespread civic engagement. The participation of inhabitants is still more embedded in traditional government than in governance. Researchers note the low level of interest of local communities in public affairs, the lack of partnership (Tykwińska-Rutkowska, 2017, p. 54), the decreasing involvement of citizens and the withering of civil dialogue, as well as the dysfunction of participation and the artificial nature of some institutions (Radzik-Maruszak, 2019, p. 267). There has been a noticeable decrease in residents being interested in the civic budget.

Nevertheless, in Poland, attempts to move from a hierarchical and bureaucratic style of governance to social partnership based on cooperation have been observed. Among others, this is demonstrated by gradually increasing the cooperation of the local government with non-governmental organizations, or by the increasing number of cities following the civic budget procedure. An increasing number of local governments are attempting to communicate with residents (websites, regular public meetings, special telephone lines, civic panels). In 2018, the mechanisms of participation and civic control in local government were strengthened. Also, the principle of openness of local government bodies was enhanced (ustawa z dnia 11 stycznia 2018). The introduced regulations correspond with the implementation of the concept of governance postulated for many years. However, they do not constitute a radical turn towards participatory management, but rather a correction of the existing model of local government democracy and a way to popularize mechanisms previously used by some local governments. The concept of governance in Poland is a realistic perspective, but it encounters a number of barriers, such as the weakness of civil society, low social trust, a traditional administrative culture oriented towards hierarchical activities, the reluctance of some local government officials to enter into partnerships and encourage the involvement of society, or insufficient cooperation between local government units. 


\section{Summary}

The analyses show that in the process of the implementation of management reforms in the local government systems of the two countries there have been both convergent and divergent trends. The strong decentralization of the system and competences visible at the beginning of the system transformation imply a convergent trend. After 2010, in Hungary the earlier decentralization process has been reversed and the country has embarked on the path of radical centralization. In Poland, clear recentralizing trends have been present since 2015, revealing a certain degree of convergence with the policy of the government of Viktor Orbán - the scale of this phenomenon, however, has been much smaller than in Hungary (see: Rajca, 2019, pp. 76-89). There has been a clear convergence in NPM-inspired reforms (privatization, outsourcing). The convergence in the privatization policies in Poland and Hungary has been influenced by signals about the growing financial problems of the welfare state, the dominance of NPM trends in Europe and the world, as well as international organizations such as the EU or OECD. After 2010, Hungary has strongly opposed NPM embarking on the nationalization and remunicipalization of assets and services. Since 2015, Poland has seen trends towards the nationalization of state property, which can be perceived as a certain convergence with Hungarian policy. However, it is difficult to confirm the phenomenon of remunicipalization, which is demonstrated by individual cases rather than the general tendency. The gradual introduction of mechanisms conducive to social participation to solve local problems is an example of a convergent trend. The weakness of civil society but also of public institutions has hindered the full implementation of the concept of governance.

Due to the crisis and disappointment with the earlier "neoliberal" state, the recent neoliberal philosophy has been rejected in Hungary in recent years, and there has been a shift towards nationalization, remunicipalization and the neo-Weberian state (Pálné Kovács, 2012, p. 195). It should be emphasized, however, that the neo-Weberian concept advocates the separation of tasks and competences of politicians and the civil service, while the Hungarian public administration reforms have taken the opposite direction. The political loyalty of officials has been more appreciated than professional skills. Also, according to many studies and documents of international institutions, Hungarian reforms have taken the direction opposite to the neo-Weberian rule of law. Public administra- 
tion reforms in Hungary after 2010 reflect a coherent vision of a strong and centralized state intended to ensure the effective resolution of social problems. The market and civil society have been given a subordinate role in solving problems. As far as the Polish local government model is concerned, it can be observed that during the period of political transformation it has been affected (similarly to Hungarian local government) by the implementation of solutions derived from different management paradigms, which are in many respects contradictory. Currently, it is difficult to indicate one organizational model constituting a coherent whole. Polish public administration is characterized by a high degree of acceptance of hierarchical methods of operation (Mazur, Możdżeń, Oramus, 2018, p. 804). In the Polish local government system the Weberian management model dominates (see: Kulesza, 2009, pp. 7-22). Implementing the ideas of new Weberianism requires a change of orientation from the perspective of the lawful execution of tasks to meeting the needs of citizens and management development.

Reforming public administration, including local government, should foster specific national and local socio-economic, territorial, political, cultural and mental conditions, and not rely on the uncritical implementation of the currently fashionable paradigm, as the quality of local democracy and the effectiveness of public service delivery do not just depend on the selected local government model. A much better solution is to use different models in different contexts. The problem is that modern public management models are excessively idealistic and too general or partial, and do not provide guidance as to under which conditions they will be effective (Ropret, Aristovnik, Kovač, 2018/2019, p. 130). Another problem is the misconception that subsequent reforms will make the whole system better. By introducing new methods of providing public services, the administration creates new problems that it needs to solve.

\section{Bibliography}

Forum samorządowe (2013), Andrzej Arendarski: Spótki komunalne trzeba prywatyzować, http://www.forumsamorzadowe.pl/aktualnosci/1420.html, 4.11.2019.

GUS, (Central Statistical Office) (2015), Zmiany strukturalne grup podmiotów gospodarki narodowej w rejestrze REGON, 2015, GUS, Warszawa.

Heinelt H., Krapp M.-Ch. (2016), Perceptions of New Public Management reforms, in: Policy Making at the Second Tier of Local Government in Europe, eds. X. Bertrana, B. Egner, H. Heinelt, Routledge, Abingdon-New York. 
Horváth T. M. (2016), From Municipalisation to Centralism: Changes to Local Public Service Delivery in Hungary, in: Public and Social Services in Europe, eds. H. Wollmann, I. Koprić, G. Marcou, Palgrave Macmillan, Basingstoke.

Kachniarz M. (2018), Reformy samorzadowe w krajach europejskich, in: Samorzad XXI wieku. Problemy, trendy, rozwiązania, eds. M. Kachniarz, R. Raczyński, Wydawnictwo Siedmioróg, Warszawa.

Kopyciński P. (2016), Neoweberyzm (neo-Weberianstate) jako sposób zarządzania w polityce innowacyjnej, "Zarządzanie Publiczne", no. 3(37).

Kudłacz M. (2015), Neoweberyzm jako nowy model zarzadzania rozwojem metropolii $w$ warunkach zglobalizowanej gospodarki, in: Sprawne państwo. Systemowe zmiany w funkcjonowaniu polskiego samorzadu terytorialnego, eds. M. Ćwiklicki, Uniwersytet Ekonomiczny w Krakowie Małopolska Szkoła Administracji Publicznej, Kraków.

Kuhlmann S., Wollmann H. (2014), Introduction to Comparative Public Administration. Administrative Systems and Reforms in Europe, Edward Elgar, Cheltenham-Northampton.

Kulesza M. (2009), O tym, ile jest decentralizacji w centralizacji, a także o osobliwych nawykach uczonych administratywistów, "Samorząd Terytorialny", no. 12 .

Mazur S., Możdżeń M., Oramus M. (2018), Public administration characteristics and performance in EU28: Poland, European Commission, Brussels.

Mikuła Ł., Walaszek M. (2016), The Evolution of Local Public Service provision in Poland, in: Public and Social Services in Europe, eds. H. Wollmann, I. Koprić, G. Marcou, Palgrave Macmillan, Basingstoke.

Ministerstwo Skarbu Państwa (2016), Raport o ekonomicznych, finansowych i społecznych skutkach prywatyzacji w roku 2015, Warszawa.

Ministerstwo Skarbu Państwa (2016), Informacja o przekształceniach i prywatyzacji mienia komunalnego za rok 2015, Warszawa.

Ministerstwo Skarbu Państwa (2015), Informacja o przekształceniach i prywatyzacji mienia komunalnego za rok 2014, Warszawa.

Odpowiedź Ministra Środowiska na interpelację poselską z dnia 31.05.2016 r., http:// orka2.sejm.gov.pl/INT8.nsf/klucz/323A0944/\%24FILE/i02569-o1.pdf, 2.11.2018.

OECD (2008), Public-Private Partnerships. In Pursuit of Risk Sharing and Value for Money, OECD, Paris.

Pálné Kovács I. et al. (2016), Farewell to Decentralisation: The Hungarian Story and its General Implications, "Croatian and Comparative Public Administration", no. 16(4).

Pálné Kovács I. (2015), Regionalism in Hungary. Assembly of European Regions Study on Regionalism, The Assembly of European Regions.

Pálné Kovács I. (2012), Roots and consequences of local government reforms in Hungary, "Revue d'etudes comparatives Est-Ouest", vol. 43, no. 3. 
Pálné Kovács I., Region-Building in Hungary - the Case of South-Transdanubia, https://www.tepav.org.tr/sempozyum/2006/bildiri/bolum2/2_2_kovacs.pdf, 10.02.2019.

Pawłowska A. (2018), Czynniki i trajektorie zmian administracji i polityk publicznych, in: Państwo w czasach zmiany, eds. M. Pietraś, I. Hofman, S. Michałowski, Wydawnictwo Uniwersytetu Marii Curie-Skłodowskiej, Lublin.

Péteri G., Decentralization in Eastern Europe: grab the moment!, Website of the MTA-DE Public Service Research Group, http://publicgoods.eu/decentralization-eastern-europe-grab-moment, 20.07.2018.

Radzik-Maruszak K. (2019), Rada gminy jako uczestnik lokalnego wspótrządzenia. Przykład Anglii, Finlandii, Polski i Stowenii, Wydawnictwo Naukowe Scholar, Warszawa.

Rajca L. (2019), Reformy samorząu terytorialnego na Wegrzech $i$ w Polsce, Dom Wydawniczy Elipsa, Warszawa.

Rajca L. (2012), Reformy samorządu terytorialnego w Anglii w latach 1997-2010, Europejskie Centrum Edukacyjne, Toruń.

Randma-Liiv T. (2008/2009), New Public Management Versus the Neo-Weberian State in Central And Eastern Europe, "The NISPAcee Journal of Public Administration and Policy", Special Issue, vol. 1, no. 2.

Ropret M., Aristovnik A., Kovač P. (2018/2019), A Content Analysis of the Rule of Law within Public Governance Models: Old vs. New EU Member States, "The NISPAcee Journal of Public Administration and Policy", vol. XI, no. 2.

Swianiewicz P. (2017), Urynkowienie, prywatyzacja i rekomunalizacja. Formy dostarczania lokalnych ustug publicznych w opiniach burmistrzów krajów europejskich, "Samorząd Terytorialny", no. 5.

Swianiewicz P. (2017), Stosunek do prywatyzacji lokalnych ustug publicznych, 27.04.2017, "Wspólnota".

Swianiewicz P. (2016), Współczesne badania nad samorządem i polityka lokalna, in: Polska gmina 2015, ed. G. Gorzelak, Warszawa.

Sześciło D. (2014), Wprowadzenie, in: Administracja i zarządzanie publiczne. Nauka o współczesnej administracji, ed. D. Sześciło, Wydawca Stowarzyszenie Absolwentów Wydziału Prawa i Administracji Uniwersytetu Warszawskiego, Warszawa.

Tykwińska-Rutkowska D. (2017), Młodzieżowe rady gmin i gminne rady seniorów jako forma partycypacji mieszkańców gminy (społeczności lokalnych) w samorządzie terytorialnym, "Samorząd Terytorialny", no. 9.

Ustawa z dnia 11 stycznia 2018 r. o zmianie niektórych ustaw $w$ celu zwiększenia udziału obywateli $w$ procesie wybierania, funkcjonowania i kontrolowania niektórych organów publicznych, Dz. U. 2018, poz. 130.

Ustawa z dnia 10 czerwca 2016 r. o zmianie ustawy o działalności leczniczej i niektórych innych ustaw, Dz. U. 2016, poz. 960.

Ustawa z dnia 16 grudnia 2010 r. o publicznym transporcie zbiorowym, Dz. U. 2015, poz. $1440 \mathrm{ze} \mathrm{zm}$. 
Van de Walle S., Hammerschmid G., Andrews R., Bezes P. (2016), Introduction: public administration reforms in Europe, in: Public Administration Reforms in Europe. The View from the Top, eds. G. Hammerschmid, S. Van de Walle, R. Andrews, P. Bezes, Edward Elgar, Cheltenham-Nothampton.

Wąsowicz K. (2018), Efektywność przedsiębiorstw użyteczności publicznej lokalnego transportu publicznego, Uniwersytet Ekonomiczny w Krakowie, Kraków.

Wollmann H. (2016), Public and Social Services in Europe: From Public and Municipal to Private Provision - And Reverse?, in: Public and Social Services in Europe, eds. H. Wollmann, I. Koprić, G. Marcou, Palgrave Macmillan, Basingstoke.

\section{Reformy zarządzania w polskim i węgierskim samorządzie terytorialnym}

\section{Streszczenie}

Celem opracowania jest porównanie reform zarządzania w węgierskim i polskim samorządzie terytorialnym wprowadzanych od początku transformacji ustrojowej i w okresie dwóch pierwszych dekad XXI wieku. Analizy wskazują, że samorządy obu badanych państw doświadczyły implementacji rozwiązań zaczerpniętych z różnych i pod wieloma względami sprzecznych paradygmatów zarządzania. We wprowadzaniu reform zarządzania w samorządzie terytorialnym obu państw występowały zarówno trendy zbieżne, jak i rozbieżne. Reformy na Węgrzech po 2010 roku odzwierciedlają spójną wizję silnego i scentralizowanego państwa mającego zapewnić skuteczne rozwiązywanie problemów społecznych. Rynkowi i społeczeństwu obywatelskiemu wyznaczono niewielką rolę. Odnośnie polskiego samorządu terytorialnego, obecnie trudno wskazać jeden organizacyjny model stanowiący spójną całość.

Słowa kluczowe: modele zarządzania, Polska, Węgry

Data przekazania tekstu: 13.01.2020; data zaakceptowania tekstu: 29.01.2020. 